\title{
KARAKTERISTIK, PENGELOLAAN DAN PEMERIKSAAN BADAN HUKUM YAYASAN DI INDONESIA
}

(Character, Management and Examination Charity Foundation in Indonesia)

\author{
Y. Sogar Simamora \\ Fakultas Hukum Universitas Airlangga Surabaya \\ Jl. Darmawangsa Dalam Selatan Surabaya, 60222 Jawa Timur
}

Naskah diterima: 04 Mei 2012; revisi: 28 Juni 2012; disetujui: 09 Juli 2012

\begin{abstract}
Abstrak
Yayasan adalah badan hukum yang didirikan untuk mencapai tujuan tertentu di bidang sosial, keagamaan, dan kemanusiaan. Pendirian yayasan diawali dengan pemisahan harta kekayaan pendiri untuk dimasukkan sebagai modal awal yayasan. Pemisahan harta kekayaan pendiri ke dalam yayasan tersebut tidak dapat diberi makna investasi karena secara filosofi pendirian yayasan bersifat nirlaba. Dalam praktiknya terjadi penyimpangan dalam pengelolaan, konflik antar pengurus serta penyalahgunaan lembaga yayasan. Tulisan ini akan mengkaji bagaimana prinsip dan aturan hukum dalam pengelolaan yayasan sebagai hukum privat dan bagaimana pengelolaan oleh organ yayasan berdasarkan prinsip transparansi dan akuntabilitas. Dengan menggunakan metode yuridis normatif dapat disimpulkan bahwa berdasarkan cara pendiriannya yayasan tergolong badan hukum privat. Prinsip transparansi dan akuntabilitas dalam mewujudkan good governance dalam pengelolaan yayasan diperlukan untuk memastikan bahwa organ yayasan menjalankan tugasnya semata-mata untuk mencapai tujuan yayasan, selain itu perlu adanya pemeriksaan terhadap yayasan untuk memastikan organ yayasan tidak melakukan pelanggaran hukum dan lalai dalam menjalankan tugasnya
\end{abstract}

Kata kunci: yayasan, pengelolaan, pemeriksaan, transparansi, akuntabilitas

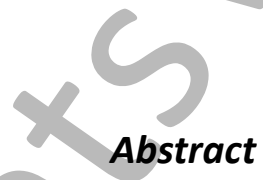

The foundation is a legal entity established to achieve specific goals in the areas of social, religious, and humanitarian. The establishment of the foundation begins with the separation of founder(s) assets to be incorporated as the authorized capital foundation. Separation founder(s) assets into foundations can not be given meaning as investment, because the founding foundations philosophy is non-profit. In practice there are deviations in the management of the conflict between the board and the abuse of the institution foundation. This paper will examine how the principles and the rule of law in the management of a foundation and how management by organs of the foundation based on principles of transparency and accountability. By using normative methods can be concluded that based on the way its establishment, the foundation belonging to private legal entities. Principles of transparency and accountability in achieving good governance in the management foundation required to ensure that the foundation organ duties solely to achieve the purpose of the foundation, in addition to the need for an examination of the foundation to ensure that the fund did not perform organ offense and negligent in performing their duties.

Keywords: foundations, management, inspection, transparency, accountability 


\section{A. Pendahuluan ${ }^{1}$}

Yayasan sebagai badan hukum mempunyai karakter yang khas. Jenis badan hukum ini lahir karena adanya suatu perbuatan hukum yakni pemisahan sejumlah kekayaan dari pendiri dengan tujuan tertentu. Tujuan ini umumnya bukan untuk meraih keuntungan. Dalam Undang-Undang Nomor 16 Tahun 2001 tentang Yayasan (UU No. 16/2001) yang selanjutnya diubah dengan Undang-Undang Nomor 28 Tahun 2004 tentang Perubahan atas UU No. 16/2001 (UU No. 28/2004) tujuan yayasan ditetapkan secara limitatif yakni, sosial, keagamaan dan kemanusiaan. Di samping kekayaan dan tujuan, diperlukan organisasi untuk menuju tercapainya tujuan pendirian.

Dalam UU No. 16/2001 diatur tiga organ yayasan, yakni: pembina, pengurus dan pengawas. Tiga organ inilah yang mempunyai tanggung jawab dan kewenangan dalam pengelolaan yayasan agar tujuan yayasan tercapai sesuai dengan maksud pendiriannya.

Kenyataan dalam praktik menunjukkan adanya penyimpangan dalam pengelolaan, konflik antar pengurus atau penyalahgunaan lembaga yayasan. Fokus tulisan ini diarahkan pada pembahasan tentang prinsip-prinsip dan aturan hukum dalam pengelolaan yayasan sebagai badan hukum privat, dan pengelolaan oleh organ yayasan bertumpu pada prinsip transparansi dan akuntabilitas dalam kaitannya dengan upaya mencegah penyalahgunaan lembaga yayasan.

\section{B. Permasalahan}

Dari uraian di atas, dirumuskan permasalahan sebagai berikut:

1. Bagaimana karakteristik dan aturan hukum dalam pendirian yayasan sebagai hukum privat?

2. Bagaimana pengelolaan dan pemeriksaan organ yayasan berdasarkan prinsip transparansi dan akuntabilitas?

\section{Metodologi Penelitian}

Penulisan ini didasarkan pada penelitian hukum normatif. Bahan hukum yang digunakan adalah bahan hukum yang diperoleh melalui dari buku kepustakaan, artikel, serta peraturan perundang-undangan yang berkaitan dengan karakteristik, pengelolaan dan pemeriksaan badan hukum yayasan di Indonesia.

\section{Pembahasan}

\section{Karakteristik Badan Hukum Yayasan}

Dalam Pasal 1 angka 1 UU No. 16/2001 ditentukan yayasan adalah badan hukum yang terdiri atas kekayaan yang dipisahkan dan diperuntukan untuk mencapai tujuan tertentu di bidang sosial, keagamaan, dan kemanusiaan, yang tidak mempunyai anggota. Perlu penjelasan mengenai batasan tersebut.

\section{a. Yayasan Sebagai Badan Hukum}

Seperti halnya perseroan terbatas (PT) dan koperasi, yayasan adalah badan hukum yang tergolong badan hukum privat. Ini untuk membedakan dengan badan hukum publik.

Tulisan ini diolah kembali dari makalah yang penulis sampaikan dalam Seminar Tentang Aspek-Aspek Hukum Yayasan Di Indonesia, yang diselenggarakan Badan Pembinaan Hukum Nasional, pada 26 April 2012 di Surabaya. 
Perbedaan antara badan hukum publik dan privat terutama terletak pada cara pendiriannya sebagaimana diatur dalam Pasal 1653 KUH Perdata. Cara pendirian dalam hal ini terkait dengan undangundang yang mengatur bagaimana badan hukum itu didirikan. Bahwa suatu yayasan didirikan oleh lembaga publik (pemerintah) tidak mengubah statusnya sebagai badan hukum privat. Sekalipun selaku pendiri adalah organ publik atau pejabat publik, yayasan yang didirikan tidak mempunyai wewenang publik melainkan hanya dalam lingkup hubungan keperdataan (privat). Status yayasan juga tetap sebagai badan hukum privat sekalipun kekayaan awal yang dimaksud dalam pendirian berasal dari atau merupakan aset (keuangan) negara. $^{2}$

Demikian juga terkait dengan lapangan kegiatan yayasan. Kegiatan yayasan dalam beberapa hal ditujukan untuk kepentingan umum atau menjalankan fungsi yang menjadi tugas pemerintah, misalnya dalam lapangan pendidikan atau pelayanan kesehatan (rumah sakit). Sekalipun kegiatan yayasan ditujukan untuk kepentingan umum atau secara fungsional membantu pemerintah, menurut Penulis hal tersebut tidak mengakibatkan yayasan yang bersangkutan berubah bentuknya menjadi badan hukum publik.

Sekalipun suatu yayasan turut berperan serta membantu pemerintah menjalankan fungsi pemerintahan, apa yang dilakukan oleh yayasan itu tidak dapat dikualifikasikan sebagai perbuatan yang dilakukan oleh badan tata usaha negara. Jika dalam situasi demikian yayasan dinilai memperoleh kewenangan atributif dari undangundang, dan karena itu jika yayasan menerbitkan suatu keputusan dianggap sebagai keputusan tata usaha negara maka penilaian yang demikian menurut Penulia tidak tepat. ${ }^{3}$ Penilaian yang demikian ini akan mengaburkan status yayasan sebagai badan privat.

\section{b. Kekayaan Yang Dipisahkan}

Elemen utama dari yayasan adalah harta kekayaan yang dipisahkan dari kekayaan pendirinya. Perbuatan hukum memisahkan mengandung makna ada kesukarelaan dari pendiri untuk melepaskan suatu kekayaan. Dengan perbuatan itu, pendiri demikian juga ahli warisnya, tidak lagi berhak atas kekayaan yang dipisahkan dan dilepas itu. Kekayaan yang dipisahkan itu kemudian berubah statusnya sebagai badan hukum, yakni yayasan. Dengan demikian tidak ada orang atau badan yang berstatus sebagai pemilik atas suatu yayasan.

Kekayaan yang dipisahkan untuk pendirian yayasan dapat berupa berbagai jenis benda. Untuk yayasan yang didirikan oleh orang Indonesia, jumlah kekayaan awal yang berasal dari pemisahan harta kekayaan pribadi paling sedikit senilai Rp 10.000.000,00 (sepuluh juta rupiah), sedangkan untuk yayasan yang didirikan oleh orang asing, atau orang asing dengan orang

2 Mengenai Yayasan Pemerintah periksa, Lex Rieffel dan Karaniya Dharmasaputra, Di Balik Korupsi Yayasan Pemerintah, (Jakarta: Freedom Institute, 2008).

3 Dalam Pasal 54 ayat (2) Undang-undang Nomor 20 Tahun 2003 tentang Sistem Pendidikan Nasional diatur bahwa masyarakat dapat berperan serta sebagai sumber, pelaksana, dan pengguna hasil pendidikan. Ada yang menafsir ketentuan ini sebagai sumber kewenangan atributif bagi yayasan yang bergerak di bidang pendidikan. Implikasinya keputusan yang diterbitkan oleh yayasan tersebut dikualifikasikan sebagai keputusan tata usaha negara. Lihat, Putusan Nomor 13/G/20 10/PTUN. BKL. Selanjutnya, terkait pelayanan kesehatan dapat diperiksa Pasal 7 ayat (4) Undang-undang Nomor 44 Tahun 2009 tentang Rumah Sakit yang menentukan bahwa rumah sakit dapat didirikan oleh swasta yang berbadan hukum. 
Indonesia, paling sedikit senilai Rp 100.000.000,00 (seratus juta rupiah). ${ }^{4}$

Dalam kaitan dengan kekayaan yang dipisahkan, menarik untuk disimak penjelasan Pasal 9 ayat (1) UU No. 16/2001 yang menyatakan bahwa yang dimaksud "orang" adalah orang perseorangan atau badan hukum. Mengacu pada ketentuan ini maka dapat saja yayasan didirikan oleh badan hukum, baik publik maupun privat. Jika selaku pendiri adalah badan publik, maka pendirian memerlukan persetujuan dewan (parlemen) karena kekayaan yang akan digunakan untuk pendirian yayasan akan menjadi milik yayasan. Demikian juga jika selaku pendiri adalah perseroan terbatas, maka diperlukan persetujuan pemegang saham sebelum kekayaan perseroan akan dilepas sebagai kekayaan yang dipisahkan untuk tujuan pendirian yayasan. Hal yang sama akan berlaku jika suatu yayasan akan mendirikan badan hukum lainnya.

Dengan demikian secara normatif badan hukum dapat mendirikan yayasan. Namun demikian, diperlukan suatu instrumen hukum untuk mencegah dilakukannya penyalah-gunaan lembaga yayasan sebagai suatu badan hukum privat untuk kepentingan pribadi atau golongan. Transparansi dan akuntabilitas sangat diperlukan, tetapi lebih dari itu perlu penegakkan hukum yang konsisten terhadap penyalahgunaan lembaga yayasan.

Peluang untuk menyalahgunakan yayasan dapat terjadi, karena sebagaimana diatur dalam UU No. 16/2001, yayasan dapat melakukan kegiatan usaha untuk menunjang pencapaian maksud dan tujuan pendirian yayasan dengan cara mendirikan badan usaha atau ikut serta dalam suatu badan usaha. ${ }^{5}$

Pada umumnya dipahami bahwa yayasan adalah suatu badan hukum yang kegiatannya tidak berorientasi mencari keuntungan (nirlaba). Di sisi lain, badan usaha adalah untuk mencari keuntungan. Agaknya terdapat kontradiksi antara ketentuan tersebut di atas dengan Pasal 1 angka 1 UU No. 16/2001 yang menentukan bahwa tujuan yayasan adalah di bidang sosial, keagamaan dan kemanusiaan.

Yayasan memerlukan dana untuk menjalankan kegiatannya. Jika dana itu semata-mata bersumber dari kekayaan awal, tentu tujuan pendirian yayasan sulit tercapai.

Dana yang diperoleh dari kegiatan usaha memang diperlukan untuk mencukupi kebutuhan operasional yayasan dan pengembangan yayasan. Namun demikian, jika kegiatan itu dilakukan atas nama yayasan maka segala pendapatan yang diperoleh adalah milik yayasan. Demikian sebaliknya jika kegiatan itu menimbulkan suatu kewajiban pembayaran kepada pihak lain maka hal itu merupakan kewajiban yayasan. Prinsipnya, setiap transaksi dengan pihak lain yang menimbulkan hak dan kewajiban bagi yayasan wajib dicantumkan dalam laporan tahunan. ${ }^{6}$ Dalam hal yayasan memperoleh bantuan atau sumbangan maka hal tersebut juga merupakan milik yayasan. Itulah sebabnya setiap kekayaan yayasan dilarang dialihkan kepada pembina, pengurus maupun pengawas. Pengecualian terhadap ketentuan ini adalah pengurus dapat diberi gaji, upah atau honorarium sepanjang pengurus tersebut bukan

Pasal 6 Peraturan Pemerintah No. 63 Tahun 2008 tentang Pelaksanaan Undang-undang tentang Yayasan Pasal 3 ayat (1) UU No. 16/2001.

Pasal 49 UU No. 16/2001. 
pendiri yayasan dan tidak terafiliasi dengan pendiri, pembina dan pengawas. ${ }^{7}$

\section{c. Tujuan Pendirian Yayasan}

Kekayaan yang dipisahkan dari kekayaan pendiri ditujukan untuk tujuan tertentu dalam lingkup sosial, keagamaan dan kemanusiaan. Tidak ada penjelasan lebih lanjut tentang hal ini. Tetapi dalam penjelasan Pasal 8 UU No. 16/2001 disebutkan bahwa kegiatan usaha dari badan usaha yayasan mempunyai cakupan yang luas, termasuk antara lain hak asasi manusia, kesenian, olahraga, perlindungan konsumen, pendidikan, lingkungan hidup, kesehatan dan ilmu pengetahuan. Dengan demikian yayasan dapat melakukan kegiatan apa saja sepanjang tidak bertentangan dengan ketertiban umum, kesusilaan dan peraturan perundang-undangan yang berlaku.

Jika kita memperhatikan penjelasan Pasal 8 di atas, agaknya perlu dipertimbangkan rumusan:

"...tujuan tertentu di bidang sosial, keagamaan, dan kemanusiaan..."

sebagaimana tertuang dalam Pasal 1 angka 1 UU No. 16/2001. Tidakkah rumusan itu cukup "tujuan tertentu" tanpa harus dikaitkan dengan tujuan di bidang sosial, keagamaan dan kemanusiaan.

Sebagaiperbandingan dapatkita lihat rumusan foundation dalam Article 285 The Civil Code of the Netherlands (CCN) yang menentukan:

"A foundation is a legal person created by a legal act which has no members and whose purpose is to realize an object stated in its articles using capital allocated to such purpose.".8

\section{d. Tidak Mempunyai Anggota}

Berbeda dengan badan hukum koperasi atau perkumpulan yang berbadan hukum, yayasan tidak mempunyai anggota. Pembina, pengurus dan pengawas dalam yayasan bukanlah anggota melainkan organ yayasan. Ini dapat dipahami karena dalam badan hukum yayasan, badan hukum terbentuk karena adanya harta kekayaan yang dipisahkan. Sedangkan dalam koperasi dan perkumpulan, badan hukum terbentuk karena adanya anggota.

Karena yang menjadi unsur esensial dari yayasan adalah harta kekayaan maka jika kemudian dalam perjalanannya suatu yayasan habis kekayaannya maka yayasan itu tentu tidak dapat lagi menjalankan kegiatan guna mencapai tujuannya. Artinya, secara materiil yayasan bubar. Dalam hal yayasan tidak mampu membayar utang setelah dinyatakan pailit maka pembubaran terjadi karena adanya putusan (penetapan?) pengadilan negeri. ${ }^{9}$

\section{e. Pendirian Yayasan dan Anggaran Dasar}

Terkait pendirian yayasan, Pasal 9 UU No. 16/2001 mengatur bahwa yayasan didirikan oleh satu orang atau lebih dengan memisahkan sebagian harta kekayaan pendirinya, sebagai kakayaan awal. Pendirian itu dilakukan dengan akta notaris dan dalam bahasa Indonesia. ${ }^{10}$

Lahirnya yayasan sebagai badan hukum pada saat setelah akta pendirian memperoleh pengesahan dari Menteri. Dengan demikian organ yayasan belum dapat mengikatkan yayasan dengan pihak lain dalam suatu hubungan hukum

Pasal 5 UU No. 28/2004 jo. UU No. 16/2001.

Hans Warendorf, et.al., The Civil Code of the Netherlands, (US: Kluwer Law International, 2009).

Pasal 62 huruf c UU N0.16/2001.

10 Sama seperti di Belanda, pendirian juga harus dengan akta notaris (notarial deed). Lihat, Article 286 CCN. 
sebelum diperoleh pengesahan atas anggaran dasar tersebut. Pelanggaran terhadap prinsip ini mengakibatkan organ yang melakukan perbuatan hukum atas nama yayasan akan bertanggung gugat secara pribadi.

Prinsip ini selanjutnya dapat kita lihat dalam UU No. 28/2004 yang menentukan bahwa perbuatan hukum yang dilakukan oleh pengurus atas nama yayasan sebelum yayasan memperoleh status badan hukum menjadi tanggung jawab pengurus secara tanggung renteng. ${ }^{11}$

Anggaran Dasar adalahaturan internal yayasan yang harus dipatuhi baik oleh pembina, pengurus maupun pengawas. Dalam hal terjadi dugaan penyimpangan atau perselisihan maka Anggaran Dasar menjadi dasar bagi penegak hukum baik penyidik, hakim maupun auditor. Dalam kaitan ini sangat penting untuk memastikan keabsahan suatu Anggaran Dasar sebelum diberikan pengesahannya. Dalam Pasal 14 UU N0. 16/2001, ditentukan Anggaran Dasar Yayasan sekurangkurangnya memuat:

1) Nama dan tempat kedudukan;

2) Maksud dan tujuan serta kegiatan untuk mencapai maksud dan tujuan tersebut;

3) Jangka waktu pendirian;

4) Jumlah kekayaan awal yang dipisahkan dari kekayaan pribadi pendiri dalam bentuk uang atau benda;

5) Cara memperoleh dan penggunaan kekayaan;

6) Tata cara pengangkatan, pemberhentian, dan penggantian anggota pembina, pengurus dan pengawas;

7) Hak dan kewajiban anggota pembina, pengurus, dan pengawas;
8) Tata cara penyelenggaraan rapat organ yayasan;

9) Ketentuan mengenai perubahan Anggaran Dasar;

10) Penggabungan dan pembubaran yayasan; dan,

11) Penggunaan kekayaan sisa likuidasi atau penyaluran kekayaan yayasan setelah pembubaran.

\section{Pengelolaan dan Pemeriksaan Terha- dap Yayasan}

Untuk dapat melaksanakan aktivitas guna mencapai tujuan pendiriannya, suatu badan hukum seperti manusia memerlukan organ. Suatu badan hukum membentuk kehendaknya dengan perantaraan alat-alat atau organorgannya seperti manusia yang mengungkapkan kehendaknya melalui mulut atau tangannya. Seperti halnya manusia biasa, badan hukum adalah organisme yang hidup. Badan hukum sebagai pendukung hak dan kewajiban, mewujudkannya melalui organ-organnya. Inilah esensi teori Organ. ${ }^{12}$

Dalam kaitan dengan badan hukum yayasan, UU No. 16/2001 menentukan tiga jenis organ, yaitu: pembina, pengurus dan pengawas. Pembina adalah organ yayasan yang mempunyai kewenangan yang tidak diserahkan kepada pengurus atau pengawas oleh undang-undang atau anggaran dasar. ${ }^{13}$ Sedangkan pengurus adalah organ yayasan yang melaksanakan kepengurusan yayasan ${ }^{14}$, dan pengawas adalah organ yayasan yang bertugas melakukan pengawasan serta memberi nasihat

Pasal 13 UU No. 28/2004 jo. UU No. 16/2001.

Chidir Ali, Badan Hukum, (Bandung: Alumni, 2005), hlm. 32-33.

Pasal 28 UU No. 16/2001.

14 Pasal 31 (1) UU No. 16/2001. 
kepada pengurus dalam menjalankan kegiatan yayasan. ${ }^{15}$

Kewenangan organ Pembina meliputi: keputusan perubahan anggaran dasar, pengangkatan dan pemberhentian pengurus dan pengawas, penetapan kebijakan umum yayasan, pengesahan program kerja dan rancangan anggaran tahunan, dan penetapan keputusan mengenai penggabungan atau pembubaran yayasan. ${ }^{16}$

Siapa yang dapat menjadi Pembina diatur dalam Pasal 28 ayat (3) UU No. 16/ 2001. Dalam hal ini yang dapat diangkat adalah orang perseorangan selaku pendiri atau orang yang dinilai mempunyai dedikasi tinggi untuk mencapai tujuan yayasan.

Berapa jumlah pembina tidak diatur dalam undang-undang. Dengan demikian dimungkinkan hanya satu orang pembina dalam suatu yayasan. Mengingat kewenangan yang ada maka pembina dapat membuat keputusan sesuka hati karena tidak ada mekanisme check and balances.

Mengenai pengangkatan dan pemberhentian pengurus misalnya, pembina dapat menjalankan kewenangannya berdasarkan pertimbangan subjektif dirinya sendiri. Dalam Pasal 31 ayat (3) UU No. 16/2001 disebutkan bahwa dalam hal pengurus dinilai merugikan yayasan maka pembina dapat diberhentikan sebelum berakhir masa kepengurusannya.

Ini adalah salah satu kelemahan yang dapat dimanfaatkan untuk menyalahgunakan lembaga yayasan. Idealnya Pembina dalam bentuk dewan dengan jumlah anggota sekurang-kurang lima orang dan dalam jumlah ganjil. Ini untuk menyelaraskan dengan ketentuan dalam Pasal 30 UU No. 16/2001 yang mengatur bahwa rapat pembina sekurang-kurangnya sekali dalam setahun. Tentu tidak perlu rapat jika hanya ada satu orang pembina.

Demikian juga halnya syarat persetujuan pembina dalam hal pengalihan atau pembebanan kekayaan yayasan sebagaimana diatur dalam Pasal 37 UU No. 16/2001. Yang lebih penting adalah terkait Pasal 57 ayat (4) UU No. 16/2001 yang mengatur qorum rapat dalam rangka penggabungan yang mensyaratkan $3 / 4$ dari jumlah anggota. Qorum $3 / 4$ tidak mungkin terpenuhi jika jumlah pembina tiga orang, jumlah empat membuka peluang adanya suara sama dalam voting.

Mengacu pada ketentuan Pasal 28 (2) (e) UU No.16/2001 yangmengaturtentangkewenangan dalam penggabungan dan pembubaran yayasan, seharusnya diatur juga qorum dalam rangka pembubaran Yayasan. Tetapi ternyata tentang hal ini tidak diatur dalam Bab $X$ tentang Pembubaran mulai pasal 62 sampai pasal 68. Dari sisi perancangan perundang-undangan ini dapat dikategorikan bad law seperti yang dikemukakan oleh Atiyah:

Laws may be bad because they are technically bad; for instance, because they are obscure, ambiguous, internally inconsistent, difficult to discover, or hard to apply to a variety of circumstances. And secondly, laws be substantively bad simply in the sense that they produce unacceptable results, injustice or plain idiocy, or less extremely, because they are inefficient and expensive, or produce inconsistency or anomaly between like cases. $^{17}$

15 Pasal 40 UU No. 16/2001.

16 Pasal 28 (2) UU N0.16/2001.

17 P.S. Atiyah, Law \& Modern Society, (New York: Oxford University Press, 1995), hlm. 203. 
Selanjutnya mengenai organ Pengurus, Pasal 35 UU No. 16/2001 menentukan:

1) Pengurus bertanggung jawab penuh atas kepengurusan yayasan dan berhak mewakili yayasan baik di dalam maupun diluar pengadilan.

2) Setiap Pengurus menjalankan tugas dengan itikad baik dan penuh tanggung jawab.

3) Setiap Pengurus bertanggung jawab penuh secara pribadi apabila yang bersangkutan dalam menjalankan tugasnya tidak sesuai dengan Anggaran Dasar, yang mengakibatkan kerugian Yayasan atau pihak ketiga.

Kewenangan dalam menjalankan tindakan kepengurusan pada organ Pengurus meliputi segenap tindakan dalam ruang lingkup kepengurusan. Dalam badan hukum perseroan terbatas hal ini lazim disebut daden van beheer. ${ }^{18}$

Untuk tindakan jenis ini pengurus mempunyai kebebasan sejauh tindakan itu dilakukan untuk kepentingan dan tujuan yayasan serta dengan itikad baik. Limitasi atas kewenangan pengurus adalah adalah dalam tindakan yang mengakibatkan beralihnya kekayaan atau membebani kekayaan. Ini lazim disebut daden van beschikking. ${ }^{19}$

Dalam tindakan jenis yang kedua ini limitasi dapat kita jumpai dalam Pasal 37 ayat (1) UU No. 16/2001 yang menentukan bahwa Pengurus tidak berwenang mengikat Yayasan sebagai penjamin utang, mengalihkan kekayaan yayasan kecuali atas persetujuan pembina, dan membebani kekayaan yayasan untuk kepentingan pihak lain. Lebih lanjut dalam dalam Pasal 37 ayat (2) ditentukan bahwa Anggaran
Dasar dapat membatasi kewenangan pengurus dalam melakukan perbuatan hukum untuk dan atas nama yayasan. Menarik untuk diperhatikan penjelasan ketentuan ini yang menyatakan:

Jika Pengurus melakukan perbuatan hukum untuk dan atas nama Yayasan, Anggaran Dasar dapat membatasi kewenangan tersebut dengan menentukan bahwa untuk perbuatan hukum tertentu diperlukan persetujuan terlebih dahulu dari Pembina dan/atau Pengawas, misalnya untuk menjaminkan kekayaan Yayasan 20 guna membangun sekolah atau rumah sakit.

Jika pembentuk undang-undang memaksudkan tindakan yang perlu dibatasi termasuk juga membebani atau menjaminkan kekayaan atas suatu hutang untuk kepentingan yayasan maka hal ini seharusnya diatur dalam ayat (1) nya.

Pembatasan dengan demikian ditujukan untuk tindakan yang dikelompokkan sebagai tindakan pemilikkan (daden van beschikking). Tindakan ini hanya dapat dilakukan setelah ada persetujuan tertulis dari Pembina.

Dalam menjalan tindakan kepengurusan, Pengurus wajib beritikad baik. UU No. 16/2001 tidak memberikan penjelasan lebih lanjut. Itikad baik pada hakikatnya adalah kewajiban hukum untuk bertindak secara jujur, artinya, Pengurus dituntut untuk menjalankan kewajibannya secara jujur guna tercapainya tujuan yayasan. Memang tidak ada parameter pasti untuk mengukur jujur tidaknya pengurus dalam menjalankan tugasnya.

Dalam kaitan ini ukuran itu terutama adalah Anggaran Dasar dan undang-undang. Hubungan antara Pengurus dengan yayasan adalah

18 Rudhi Prasetya, Kedudukan Mandiri Perseroan Terbatas, (Bandung: Citra Aditya Bakti, 1996), hlm. 210.

19 Ibid., hlm. 211.

20 Garis bawah oleh Penulis. 
hubungan fiduciary duty. Pengurus dalam hal ini mempunyai kewajiban untuk bertindak jujur dan patut seperti seorang agen yang mewakili prinsipalnya.

Pengurus wajib bertindak dalam koridor sebagaimana ditentukan dalam Anggaran Dasar dan berusaha mencegah timbulnya kerugian pada yayasan. Dengan demikian Anggaran Dasar merupakan instrumen utama dalam menilai apakah Pengurus telah menjalankan kepengurusan dengan itikad baik atau tidak. Kewajiban untuk bertindak atas dasar itikad baik juga dituntut oleh undang-undang. Oleh sebab itu undang-undang juga merupakan instrumen dalam menilai ada tidaknya itikad baik pada organ Pengurus yayasan. Jika terjadi masalah hukum, penerapan tentang kewajiban beritikad baik akan dinilai oleh hakim dengan bertitik tolak dari kedua instrumen tersebut. Inilah yang penting untuk dipahami oleh orang yang duduk sebagai organ yayasan, baik pembina, pengurus maupun pengawas agar terhindar dari tuntutan hukum karena tindakan-tindakan yang tergolong ultra vires.

Dalam hal tindakan Pengurus tidak sesuai dengan Anggaran Dasar dan mengakibatkan kerugian pada yayasan maka pengurus bertanggung jawab secara pribadi. Aturan ini mengandung prinsip ultra vires yang mengandung makna tindakan diluar batas kewenangan (beyond the power).

Sebagai contoh tentang larangan bagi pengurus untuk mengikat yayasan sebagai penjamin utang seperti diatur dalam Pasal 37 ayat (1) huruf a UU No. 16/2001. Ini adalah suatu larangan dalam mana pengurus tidak boleh melakukan atau tidak berwenang melakukan. Jika hal ini dilakukan maka atas tindakan tersebut yayasan yang diwakili tidak terikat atau tidak bertanggung gugat. Yang bertanggung gugat untuk membayar utang terhadap kreditur manakala debitur yang dijamin wanprestasi adalah Pengurus itu sendiri secara pribadi. Perjanjian penjaminan utang (penanggungan) yang dibuat dan ditandatangani oleh Pengurus atas nama yayasan demikian itu adalah batal demi hukum (nietig van rechtswege).

Organ yang mempunyai kewenangan melakukan pengawasan atas tindakan kepengurusan adalah pengawas. Di samping pengawasan, pengurus juga mempunyai tugas memberikan nasihat kepada Pengurus. Kewenangan lain yang diberikan oleh undangundang adalah memberhentikan sementara anggota Pengurus. Dalam yayasan sekurangkurangnya terdapat satu orang pengawas, dan pengawas tersebut tidak boleh merangkap sebagai Pembina atau Pengurus.

Terkait dengan kewenangan untuk memberhentikan sementara anggota pengurus, tidak ada penjelasan lebih lanjut. Sekalipun sifat pemberhentian bersifat sementara, ketentuan ini menurut hemat saya berlebihan. Di samping pemberhentian adalah kewenangan Pembina, akibat pemberhentian akan menimbulkan kevakuman kepengurusan, sekalipun hanya 7 hari. Jika pada akhirnya tentang status pemberhentian itu dikembalikan pada Pembina untuk memutuskan seperti diatur dalam Pasal 43 ayat (4) UU No. 16/2001 maka lebih baik jika sejak awal kewenangan pemberhentian sementara itu diserahkan kepada Pembina. Jika pengurus diberhentikan sementara, organ yang mana yang akan menjalankan kepengurusan interim tidak ada aturan lebih lanjut. Sebaliknya jika kewenangan itu diserahkan kepada Pembina maka Pembina dapat memberhentikan sementara Pengurus dan sekaligus mengangkat pengurus interim. 
Seperti halnya Pengurus, dalam menjalankan tugasnya, Pengawas wajib menerapkan itikad baik. Sekalipun tidak diatur adanya kewajiban untuk bertanggung gugat secara pribadi manakala terjadi kerugian pada yayasan akibat kesalahan dalam pengawasan, pengawas dapat saja turut bertanggung gugat jika tindakan Pengurus yang merugikan yayasan terjadi karena adanya andil dari pengawas. Pengawas yang mempunyai andil yang mengakibatkan adanya tindakan kesalahan oleh pengurus yang merugikan yayasan mempunyai akibat yang sama seperti pengurus, yakni bertanggung gugat secara pribadi. ${ }^{21}$ Tanggung gugat pribadi ini pada Pengawas ini juga berlaku dalam hal terjadi kepailitan pada yayasan yang terjadi akibat kesalahan dalam melakukan tugas pengawasan. ${ }^{22}$ Dalam hal yayasan pailit, dan itu terjadi karena kesalahan atau kelalaian Pengawas maka setiap anggota Pengawas secara bertanggung renteng bertanggung jawab atas kerugian tersebut.

Selanjutnya yang perlu mendapat perhatian adalah penerapan prinsip transparansi dan akuntabilitas dalam pengelolaan yayasan. Pengelolaan yayasan tidak saja mencakup tindakan pengurusan oleh organ Pengurus, tetapi juga segenap tindakan yang dilakukan oleh organ lain yakni Pembina dan Pengawas. Sekalipun tiga organ yayasan mempunyai kewenangan dan tanggung jawab berbeda namun semua tindakan yang dilakukan adalah untuk kepentingan yayasan. Prinsip transparansi dan akuntabilitas dengan demikian wajib dijalankan oleh ketiga organ tersebut.
Urgensi transparansi dan akuntabilitas diperlukan untuk memastikan bahwa organ yayasan menjalankan tugasnya semata-mata untuk mencapai tujuan yayasan, dan bukan tujuan lain. Sebagai bagian dari pilar good governance, transparansi dan akuntabilitas tidak saja perlu diterapkan oleh organ publik, tetapi juga organ privat. Sekalipun yayasan adalah organ privat, terdapat tuntutan oleh stakeholder agar kekayaan yayasan tidak digunakan untuk tujuan lain oleh organ yayasan selain daripada tujuan sebagaimana dituangkan dalam anggaran dasar.

Sekalipun dalam organ yayasan terdapat pengawas, ketiadaan transparansi potensial mengakibatkan pemanfaatan kekayaan yayasan yang tidakakuntabel. Bukantidakmungkinterjadi persekongkolan oleh tiga organ yang merugikan yayasan. Transparansi dan akuntabilitas dengan demikian juga berfungsi sebagai sarana kontrol oleh publik atas kinerja yang dilakukan oleh organ yayasan dan sekaligus untuk melindungi kekayaan yayasan agar tidak disalahgunakan. ${ }^{23}$

Transparansi dalam pengelolaan yayasan setidaknya mencakup dua hal, yakni: adanya pengumuman dalam Tambahan Berita Negara atas Anggaran Dasar, dan pengumuman laporan tahunan. Yang pertama adalah konsekuensi yayasan sebagai badan hukum. Dengan adanya pengumuman dalam TBN maka publik dapat mengakses informasi atas suatu yayasan. Sedangkan terkait pengumuman laporan tahunan, masyarakat atau publik dapat memperoleh informasi yang berhubungan dengan keadaan dan kegiatan yayasan, serta 
laporan keuangan yang terdiri atas laporan posisi keuangan pada akhir periode, laporan aktivitas, laporan arus kas, dan catatan laporan keuangan. Demikian juga jika yayasan mengadakan transaksi dengan pihak lain yang menimbulkan hak dan kewajiban bagi yayasan, transaksi tersebut juga wajib dicantumkan dalam laporan tahunan. ${ }^{24}$ Namun demikian, sekalipun laporan tahunan bersifat wajib (mandatory), tidak ada sanksi hukum atas pengabaian kewajiban ini.

Sanksi yang diatur hanya terkait larangan pengalihan kekayaan yayasan, yakni ancaman penjara lima tahun. Sedangkan pelanggaran atau pengabaian atas kewajiban-kewajiban lain, termasuk kewajiban membuat dan mengumumkan laporan tahunan, tidak kita jumpai sanksi hukumnya dalam UU No. 16/2001 dan UU N0. 28/2004. Laporan tahunan sebagai penerapan prinsip transparansi dan akuntablitias sangat penting untuk mencegah terjadinya penyalahgunaan lembaga yayasan. Oleh sebab itu diperlukan aturan yang lebih jelas jika kewajiban itu diabaikan.

Yayasan yang bagaimana yang wajib membuat dan mengumumkan laporan tahunan, UU No. 16 Tahun 2001 tidak mengatur. Artinya setiap yayasan wajib membuat dan mengumumkan laporan. Ke depan perlu dipikirkan apakah diperlukan pengecualian, misalnya untuk yayasan dengan jumlah kekayaan yang relatif kecil.

Selanjutnya yang perlu diperhatikan dalam kaitan dengan penerapan good governance dalam pengelolaan yayasan adalah pemeriksaan terhadap yayasan. Terkait pemeriksanaan, Pasal 53 ayat (1) UU No. 16/2001 menentukan bahwa pemeriksaan terhadap yayasan untuk mendapatkan data atau keterangan dapat dilakukan dalam hal terdapat dugaan bahwa organ Yayasan:

1) Melakukan perbuatan melawan hukum atau bertentangan dengan Anggaran Dasar;

2) Lalai dalam melaksanakan tugasnya;

3) Melakukan perbuatan yang merugikan Yayasan atau pihak ketiga; dan,

4) Melakukan perbuatan yang merugikan Negara.

Prosedur dalam melakukan pemeriksaan diatur lebih lanjut dalam Pasal 53 ayat (2) yang menentukan bahwa pemeriksaan hanya dapat dilakukan berdasarkan penetapan pengadilan atas permohonan tertulis pihak ketiga yang berkepentingan disertai alasan. Kejaksaan juga dapat mengajukan permohonan pemeriksaan mewakili kepentingan umum.

Terhadap permohonan pemeriksaan pengadilan dapat menolak atau mengabulkan. Jika permohonan itu dikabulkan maka pengadilan mengeluarkan penetapan bagi pemeriksaan dan mengangkat paling banyak tiga orang ahli sebagai pemeriksa untuk melakukan pemeriksaan. ${ }^{25}$ Terkait pengangkatan ahli, dalam permohonan pemeriksaan pemohon sekaligus meminta siapa ahli yang diajukan agar hakim dapat memeriksa kompetensi orang yang diajukan. Hal ini penting karena penetapan pemeriksaan tanpa pengangkatan ahli menjadi tidak bermanfaat. ${ }^{26}$

Objek pemeriksaan adalah semua dokumen dan kekayaan Yayasan. Semua dokumen dan hasil pemeriksaan dilarang untuk diumumkan

24 Pasal 49 UU No. 16/2001.

25 Pasal 54 UU No. 16/2001.

26 Gatot Supramono, op.cit., h. 131. 
atau diberitahukan kepada pihak lain. Hasil pemeriksaan wajib disampaikan kepada Ketua Pengadilan dan selanjutnya Ketua Pengadilan memberikan salinannya kepada pemohon dan yayasan yang bersangkutan.

\section{E. Penutup}

\section{Kesimpulan}

Dari uraian tersebut di atas dapat disimpulkan bahwa yayasan adalah badan hukum privat. Sekalipun dalam pendirian bertindak selaku pendiri adalah pejabat publik, dan kekayaan yang dipisahkan adalah kekayaan negara. Demikian juga terhadap yayasan yang menjalankan kegiatan untuk membantu fungsi pemerintahan, misalnya dalam bidang pendidikan atau kesehatan, status yayasan yang bersangkutan tetap sebagai badan hukum privat.

Prinsip transparansi dan akuntabilitas dalam pengelolaan yayasan diperlukan untuk memastikan bahwa organ yayasan menjalankan tugasnya semata-mata untuk mencapai tujuan yayasan, dan bukan tujuan lain dan juga dalam mewujudkan good governance dalam pengelolaan yayasan. Selain itu penerapan good governance dalam pengelolaan yayasan adalah pemeriksaan terhadap yayasan untuk memastikan organ yayasan tidak melakukan pelanggaran hukum dan lalai dalam menjalankan tugasnya.

\section{Saran}

Berdasarkan rumusan kesimpulan tersebut di atas, maka perlu penyempurnaan terhadap UU No. 16/2001 jo. UU No. 28/2004, baik menyangkut organ, khususnya pembina, maupun pengaturan sanksi yang jelas atas pelanggaran atau pengabaian atas kewajiban yayasan, misalnya kewajiban pembuatan dan pengumuman laporan tahunan. Hal ini merupakan konsekuensi penerapan prinsip transparansi dan akuntabilitas yang diiperlukan untuk mencegah penyalahgunaan lembaga yayasan.

\section{DAFTAR PUSTAKA}

\section{Buku}

Ali, Chidir, Badan Hukum, (Bandung: Alumni, 2005). Atiyah, P.S., Law and Modern Society, (Oxford: Oxford University Press, 1995).

Prasetya, Rudhi, Kedudukan Mandiri Perseroan Terbatas, (Jakarta: Citra Aditya Bakti, 1996).

Rieffel, Lex dan Dharmasaputra, Karaniya, Di Balik Korupsi Yayasan Pemerintah, (Jakarta: Freedom Institute, 2008).

Supramono, Gatot, Hukum Yayasan di Indonesia, (Jakarta: Rineka Cipta, 2008).

Warendorf, Hans, et al., The Civil Code of the Netherlands, (New York: Kluwer Law International, 2009).

\section{Makalah/Artikel/Prosiding/Hasil Penelitian}

Simamora, Yohanes Sogar, Prinsip Transparansi Dan Akuntabilitas Dalam Kontrak Pemerintah Di Indonesia, Pidato Guru Besar, Universitas Airlangga, Surabaya, 2008.

\section{Peraturan}

Undang-undang Nomor 16 Tahun 2001 tentang Yayasan

Undang-undang Nomor 28 Tahun 2004 tentang Perubahan Atas Undang-undang Nomor 16 Tahun 2001 tentang Yayasan.

Peraturan Pemerintah Nomor 63 Tahun 2008 tentang Pelaksanaan Undang-undang tentang Yayasan. 